\title{
Chronic venous leg ulcers - role of topical zinc
}

This article was published in the following Dove Press journal:

Chronic Wound Care Management and Research

3 June 2015

Number of times this article has been viewed

\section{Sara F Maher}

Physical Therapy Program, Department of Healthcare Sciences, Wayne State University, Detroit, MI, USA
Correspondence: Sarah F Maher Physical Therapy Program, Department of Healthcare Sciences, Wayne State University, 259 Mack Avenue,

Detroit, MI 4820I, USA

$\mathrm{Tel}+\mathrm{I} 3135775630$

$\mathrm{Fax}+|\mathrm{I}| 35778685$

Email sara.maher@wayne.edu
Abstract: Topical zinc has been used in the treatment of wounds for over 3,000 years, and is reported to have antiseptic, astringent, anti-inflammatory, antimicrobial, and wound healing properties. Fourteen studies were identified and reviewed, to assess the efficacy of this treatment modality as either a bandage or skin protectant in the treatment of venous ulcers. The authors of three studies reported improved healing time or success rate in wounds treated with zincbased products. However, the authors of one study attributed the faster healing rate mainly to the extra compression (that improved venous blood return), delivered by the non-elastic paste bandage, and not by the zinc oxide alone. The quality of evidence is fair, as $50 \%$ of the studies were conducted prior to 2000 and $50 \%$ of the studies utilized fewer than 45 patients randomized to two or more groups. Other treatments have been reported to be more cost-effective than zinc, including hydrocolloids, four-layer compression systems, and CircAid Thera-boots. Finally, zinc was reported to be less comfortable, less easy to use, and caused increased pain, in comparison to other products on the market. This literature review, therefore, demonstrated that current evidence is insufficient to determine the effectiveness of zinc-based products in the treatment of venous wounds. Future research is needed focusing on larger, high-quality trials with an emphasis on quality of life issues and cost-effectiveness of treatment.

Keywords: chronic wounds, leg ulcers, venous insufficiency, topical zinc

\section{Introduction}

Zinc is a metallic element widely found in water, air, and food, and is second only to iron as being the most abundant trace element in the human body. ${ }^{1,2}$ Zinc is important for several functions within the body, including antibody production, growth and development, bone metabolism, neuropsychiatric function, immune cell function, and wound healing. ${ }^{2,3}$ In fact, the skin and its appendages are rich in zinc; containing approximately $20 \%$ of the body's total supply, with the epidermis containing five to six times more zinc than the dermal layer. ${ }^{3,4}$ Symptoms of mild zinc deficiency include roughened skin and impaired wound healing. ${ }^{1,3}$ A 50\% reduction in zinc in granulation tissue and wound margins, for example, was observed in postoperative patients with slow healing wounds, compared with other postoperative patients. ${ }^{5}$

Zinc has been used medicinally for more than 3,000 years and is still used in wound care products today. ${ }^{1,2}$ Zinc sulfate is reported to have astringent and antiseptic properties, zinc chloride is an escharotic, and zinc oxide and calamine are reported to be mild antiseptics and protective agents. ${ }^{1}$ Zinc has been marketed in a variety of products as an anti-inflammatory, antimicrobial, and overall contributor to the wound healing process. ${ }^{2}$ In the literature, zinc was reported to be used in three ways 
in wound care: 1) zinc impregnated paste bandages used in conjunction with or as compression therapy; 2) topical zinc ointment used for skin protection; 3) zinc oxide used for debridement. ${ }^{2}$ However, the literature on zinc oxide in wound debridement has been primarily conducted on wounds due to pressure ulcers, burns, neuropathy, and other etiologies not related to venous insufficiency. For this reason, zinc used in debridement will not be included in this review.

\section{Zinc in bandages}

Zinc impregnated bandages have been used since 1854, and are made with open-weave bleached cotton impregnated with a zinc oxide paste with a concentration of zinc between $6 \%$ and $15 \%{ }^{2,4}$ Zinc impregnated bandages can be divided into five categories - those containing zinc; zinc and calamine; zinc, calamine, and clioquinol; zinc and coal tar; and zinc and ichthammol. ${ }^{2,4}$ One of the common applications of zinc impregnated bandages is in the form of an Unna boot. In this application, gauze dressing impregnated with zinc paste is wrapped around a patient's leg from the toes to below the knees. The dressing provides compression in a semi-solid mold around the extremity. ${ }^{6}$ Eight studies from the literature review compared Unna boots with other common treatments for patients with venous ulcers. The authors of the earliest study from 1985, randomly assigned 21 patients with stasis leg ulcers to treatment with either Unna boots $(n=10)$ or elastic stockings with graded compression $(n=11){ }^{7}$ The authors reported no statistically significant difference in healing success rate between the two treatments; however, patients who were treated with Unna boots healed in a shorter amount of time (7.3 weeks versus 18.4 weeks). In the early 1990s, authors of a prospective, randomized study evaluated the use of an Unna boot against a hydrocolloid dressing combined with compression from a Coban wrap in 13 patients. ${ }^{8}$ During the first 4 weeks of treatment, the ulcers treated with hydrocolloid and Coban $(n=7)$ had significantly higher healing rates $(P=0.18)$ than the ulcers treated with Unna boots $(n=6)$. At 12 weeks, the ulcers treated with the hydrocolloid plus compression continued to have better healing rates, however, the difference between the two dressing types was no longer statistically significant.

Hydrocolloid dressings were compared to Unna boots in two additional studies. In 2000, Kerstein and Gahtan ${ }^{9}$ conducted a longitudinal study of 81 patients with venous ulcers who were treated using one of three dressing types: 1) saline gauze dressing; 2) hydrocolloid dressing combined with compression therapy; 3) Unna boot. The authors reported the lowest rate of ulcer recurrence in patients treated with hydrocolloids and compression (13\%) followed by Unna boots $(21 \%)$, and finally, saline gauze (81\%). In addition, the hydrocolloid dressing with compression was reported to be the most cost-effective treatment. In a later study, Koksal and Bozkurt, ${ }^{6}$ compared treatment of ulcers using hydrocolloid dressing combined with an elastic stocking against ulcers treated by Unna boots in 60 patients with venous insufficiency. No differences were observed in healing rates, surface area reduction, or healing times of wounds between the two groups. However, patients who received treatment via the hydrocolloid dressing with elastic stocking $(n=30)$ reported significantly improved ease of use of the dressing $(P<0.0001)$, as well as significantly decreased pain $(P<0.0001)$, when compared to patients who received an Unna boot $(\mathrm{n}=30)$.

Treatment outcomes using Unna boots were also compared with compression in a variety of forms. In a randomized study from 1999, DePalma et $\mathrm{al}^{10}$ examined the effectiveness of the Unna boot compared to a CircAid Theraboot, a device consisting of a series of interlocking, nonelastic bands designed to provide sustained compression. Twenty patients with venous leg ulcers were randomly assigned to receive ulcer treatment either via the Unna boot $(n=11)$ or a CircAid Thera-boot $(n=17)$. The authors reported no differences in healing time, area healing rate, or linear healing rate between the patients. However, the total treatment costs were significantly different $(P=0.05)$ between the groups (Unna boot US\$901.73 $\pm \$ 576.45$; CircAid Thera-boot US\$559.41 $\pm \$ 290.75)$. The authors reported that these cost differences may have been attributed to physicians spending less time per visit and the need for fewer clinical visits among patients who received the CircAid Thera-boot. In 2004, 68 patients with venous leg ulcers were randomly assigned to receive treatment with either an Unna boot or a four-layer compression system. There was no difference in time to achieve wound closure for either group. The group receiving the four-layer compression, however, rated this system as easier to apply $(P=0.013)$ in comparison to the Unna boot. This study did receive funding by the manufacturer of the four-layer compression system, which should be considered when interpreting the results. Finally, a systematic review and meta-analysis, conducted in 2009, examined randomized controlled trials which compared stocking compression systems with other forms of bandaging (Unna boot, shortstretch, and multi-layer bandages). Eight studies were selected for the analysis with data from 692 patients with venous leg ulcers. The proportion of ulcers healed was 
greater with stockings than other bandages $(P<0.00001)$. In addition, the average healing time was 3 weeks shorter with stockings $(P=0.0002)$. Finally, pain was assessed in four of the eight studies, and revealed decreased pain among patients using stockings $(P=0.0001)$.

The authors of a recent study, conducted in Brazil in 2013, compared the Unna boot to simple bandages without compression in an attempt to improve treatment of leg ulcers. ${ }^{11}$ This prospective, exploratory study examined 43 patients, 32 of whom received a customized Unna boot, and eleven who received simple bandages. The patients who received the simple bandages were not eligible for an Unna boot as they had swelling, erythema, or extensive inflammation in the wound area. Results of the study found that while the patients whose ulcers were treated with an Unna boot had significantly accelerated healing initially $(P<0.05)$, after 3 months of treatment traditional bandages were found to be just as effective.

In addition to the Unna boot, topical zinc impregnated in a variety of dressing types has been compared to other treatments for venous leg ulcers. An early randomized, double-blind study from 1984, compared the efficacy of gauze impregnated with zinc oxide with the same gauze dressing lacking any topical ointment. ${ }^{12}$ Thirty-seven patients with arterial $(n=19)$ or venous $(n=18)$ leg ulcers participated in the study over an 8-week time period. (Patients with venous wounds received additional compressive therapy.) Patients treated with zinc achieved a significantly better healing rate (83\%) when compared to patients who received gauze alone $(42 \%)(P<0.05)$. The authors of a later study compared zinc oxide to hydrocolloid dressings in a prospective, randomized trial. ${ }^{13}$ Thirty-one patients with venous and arterial ulcers completed the study, and as in the previous study, compression therapy was provided to all patients with venous ulcers. Initial ulcer size decreased by $64 \%$ in patients treated with zinc oxide compared to a $48 \%$ decrease in patients treated with hydrocolloids. Both dressings had similar analgesic effects, however, two patients had to discontinue the zinc bandages due to a sensitization reaction to the dressing. Finally, in a prospective, randomized trial from $1997^{14}$ venous leg ulcers in 133 patients were treated with one of three dressings: 1) zinc paste bandages combined with compression; 2) zinc oxide-medicated stockings; 3 ) alginate dressings. ${ }^{14}$ The authors reported that ulcers healed significantly faster $(P<0.05)$ with the zinc paste bandages and compression $(n=43)$, compared to zinc stockings $(n=44)$ or alginate dressings $(n=46)$. However, the authors attributed the faster healing rate mainly to the extra compression (that improved venous blood return), delivered by the non-elastic paste bandage and not by the zinc oxide, as zinc oxide was also present in the stockings and these ulcers did not have faster healing rates.

Finally, a literature review, conducted in 2014, examined whether topical zinc-based products were effective in the treatment of chronic venous leg ulcers, and provided a summary of these findings. ${ }^{2}$ Eleven articles were included in the analysis and described a range of studies using zinc-based dressings to heal chronic venous leg ulcers. The authors determined that the literature about zinc-based products had insufficient evidence to determine whether zinc-based products were effective in healing venous ulcers. Furthermore, the authors reported that more research is needed, especially as the current evidence was of small scale (typically with fewer than 42 patients), was out-of-date (only three of the research studies were conducted within the decade of the review), and had inconsistent methodologies. A summary of studies is found in Table 1.

\section{Zinc as a skin protectant}

Zinc has been reported to have effectiveness as a barrier film to protect skin from exudate, assist in treatment of inflammation, and stimulate wound healing. ${ }^{1,3}$ In a randomized, controlled trial, 35 patients with venous leg ulcers were randomly assigned to receive either a no-sting film barrier as a wound protectant or a zinc paste compound..$^{15}$ The healing rate and decrease in wound size was not significantly different between the treatment groups. However the time to remove and re-apply the skin protectant was significantly less for the no-sting barrier film $(0.19 \pm 0.17$ minutes $)$ versus the zinc paste compound $(5.53 \pm 2.10$ minutes $)(P<0.0001)$.

A systematic review and meta-analysis examined no-sting barrier films compared to other skin protectants such as zinc oxide and petrolatum. ${ }^{16}$ Nine studies were included in the final review by the authors. The authors concluded that there were no statistically significant differences between the protective barriers, all were found to protect the periwound in a satisfactory manner. However, when the nine studies were reviewed, several themes were identified: 1) zinc oxide can interfere with dressing function (absorption and adhesion); 2) zinc oxide is difficult to remove from the periwound; 3 ) zinc oxide made visualization of the wound bed difficult. The authors concluded that the articles reviewed seemed to indicate a preference in favor of the no-sting barrier film in patient perceptions of pain control and comfort. A summary of results can be found in Table 2. 
Table I Topical zinc in bandages

\begin{tabular}{|c|c|c|c|c|}
\hline Study & Study size & Trial design & Methodology & Key findings \\
\hline $\begin{array}{l}\text { Amsler } \\
\text { et al }{ }^{19}\end{array}$ & $\begin{array}{l}8 \text { studies involving } \\
\text { patients with VLU }\end{array}$ & $\begin{array}{l}\text { Systemic review and } \\
\text { meta-analysis }\end{array}$ & $\begin{array}{l}\text { Comparison of stocking } \\
\text { compression to bandages } \\
\text { (Unna boot, short-stretch, or } \\
\text { multi-layer compression) }\end{array}$ & $\begin{array}{l}\text { Proportion of ulcers healed, average } \\
\text { time to healing, and perceptions of } \\
\text { pain were improved using stockings } \\
\text { compared to all three forms of bandages }\end{array}$ \\
\hline $\begin{array}{l}\text { Brandrup } \\
\text { et al }\end{array}$ & $\begin{array}{l}\text { 3I patients with VLU } \\
\text { or arterial leg ulcers }\end{array}$ & $\begin{array}{l}\text { Prospective } \\
\text { randomized trial }\end{array}$ & $\begin{array}{l}\text { Comparison of zinc oxide } \\
\text { impregnated dressing with a } \\
\text { hydrocolloid dressing }\end{array}$ & $\begin{array}{l}\text { No major differences in ulcer size or } \\
\text { pain. Both dressings were well tolerated } \\
\text { by patients }\end{array}$ \\
\hline $\begin{array}{l}\text { Cordts } \\
\text { et } \mathrm{al}^{8}\end{array}$ & 30 patients with VLU & $\begin{array}{l}\text { Prospective } \\
\text { randomized trial }\end{array}$ & $\begin{array}{l}\text { Comparison of hydrocolloid } \\
\text { dressing under Coban wrap } \\
\text { compression with an Unna boot }\end{array}$ & $\begin{array}{l}\text { Ulcers with hydrocolloid dressings under } \\
\text { compression healed faster than those } \\
\text { treated with an Unna boot }\end{array}$ \\
\hline $\begin{array}{l}\text { DePalma } \\
\text { et al }{ }^{10}\end{array}$ & 28 patients with VLU & $\begin{array}{l}\text { Prospective } \\
\text { randomized parallel } \\
\text { group study }\end{array}$ & $\begin{array}{l}\text { Comparison of Unna boot with } \\
\text { CircAid Thera-boot }\end{array}$ & $\begin{array}{l}\text { No difference in healing time, rate of } \\
\text { area decrease, percent area decrease, or } \\
\text { linear healing rates. CircAid Thera-boots } \\
\text { were significantly less costly than Unna } \\
\text { boots }\end{array}$ \\
\hline $\begin{array}{l}\text { Hendricks and } \\
\text { Swallow }\end{array}$ & $\begin{array}{l}2 \text { I patients with } \\
\text { stasis leg ulcers }\end{array}$ & $\begin{array}{l}\text { Random assignments } \\
\text { to two groups }\end{array}$ & $\begin{array}{l}\text { Comparison of Unna boot with } \\
\text { elastic support stockings with } \\
\text { graded compression }\end{array}$ & $\begin{array}{l}\text { No difference between healing success } \\
\text { rates. Healing time was shorter for } \\
\text { patients treated with Unna boots }\end{array}$ \\
\hline $\begin{array}{l}\text { Kerstein and } \\
\text { Gahtan' }\end{array}$ & 8I patients with VLU & Longitudinal study & $\begin{array}{l}\text { Comparison of saline gauze, } \\
\text { hydrocolloid and compression, } \\
\text { and Unna boot dressings }\end{array}$ & $\begin{array}{l}\text { Healing rates or recurrence were } 81 \% \\
\text { with saline, } 21 \% \text { with Unna boot, and } \\
\text { I } 3 \% \text { with hydrocolloid + compression. } \\
\text { Hydrocolloid may be most cost-effective }\end{array}$ \\
\hline $\begin{array}{l}\text { Koksal and } \\
\text { Bozkurt }^{6}\end{array}$ & 60 patients with VLU & $\begin{array}{l}\text { Prospective } \\
\text { comparative study }\end{array}$ & $\begin{array}{l}\text { Comparison of hydrocolloid } \\
\text { dressing under compression } \\
\text { stocking against an Unna boot }\end{array}$ & $\begin{array}{l}\text { No difference in healing rates, surface } \\
\text { reduction, or healing time between } \\
\text { treatments. Patients using hydrocolloid } \\
\text { dressings under compression stocking } \\
\text { reported less pain and ease of use } \\
\text { compared to patient using Unna boots }\end{array}$ \\
\hline Luz et al'I & 43 patients with VLU & $\begin{array}{l}\text { Prospective } \\
\text { exploratory study }\end{array}$ & $\begin{array}{l}\text { Comparison of Unna boot } \\
\text { against simple bandages without } \\
\text { compression }\end{array}$ & $\begin{array}{l}\text { While the Unna boot showed } \\
\text { significantly faster healing initially, by } \\
3 \text { months traditional bandages were } \\
\text { found to be just as effective }\end{array}$ \\
\hline $\begin{array}{l}\text { Polignano } \\
\text { et } \mathrm{al}^{20}\end{array}$ & 68 patients with VLU & $\begin{array}{l}\text { Prospective } \\
\text { randomized trial }\end{array}$ & $\begin{array}{l}\text { Compare four-layer } \\
\text { compression system with } \\
\text { Unna boot }\end{array}$ & $\begin{array}{l}\text { No differences were found in wound } \\
\text { closure time between the two } \\
\text { treatments. Four-layer compression } \\
\text { system was reported to be significantly } \\
\text { easier to apply }\end{array}$ \\
\hline $\begin{array}{l}\text { O'Connor and } \\
\text { Murphy }\end{array}$ & $\begin{array}{l}\text { I I studies involving } \\
\text { patients with VLU }\end{array}$ & Literature review & $\begin{array}{l}\text { Examination of current evidence } \\
\text { to assess whether topical zinc- } \\
\text { based products are effective } \\
\text { in promoting wound healing in } \\
\text { venous ulcers }\end{array}$ & $\begin{array}{l}\text { Scant evidence to support zinc- } \\
\text { based wound products as effective at } \\
\text { promoting healing in venous ulcers. } \\
\text { Reviewed studies were small, outdated } \\
\text { and methodologically inconsistent }\end{array}$ \\
\hline Stacey et $\mathrm{al}^{14}$ & $\begin{array}{l}\text { I33 ulcers with } \\
\text { venous insufficiency }\end{array}$ & $\begin{array}{l}\text { Prospective } \\
\text { randomized clinical } \\
\text { trial }\end{array}$ & $\begin{array}{l}\text { Comparison of zinc oxide } \\
\text { impregnated bandage under } \\
\text { compression, zinc oxide } \\
\text { impregnated stocking and } \\
\text { calcium alginate fiber dressing }\end{array}$ & $\begin{array}{l}\text { Improved healing with zinc oxide } \\
\text { impregnated bandage under } \\
\text { compression. May be due to } \\
\text { compression and not zinc alone }\end{array}$ \\
\hline $\begin{array}{l}\text { Strömberg and } \\
\text { Ågren }\end{array}$ & $\begin{array}{l}37 \text { patients with } \\
\text { arterial and VLU }\end{array}$ & $\begin{array}{l}\text { Randomized double } \\
\text { blind study }\end{array}$ & $\begin{array}{l}\text { Comparison of gauze } \\
\text { compression with zinc oxide } \\
\text { to gauze compression alone }\end{array}$ & $\begin{array}{l}\text { Zinc with gauze compression had a } \\
\text { significantly higher healing success rate } \\
\text { than gauze alone }\end{array}$ \\
\hline
\end{tabular}

Abbreviation: VLU, venous leg ulcers.

\section{Patient focused outcomes when using zinc}

Despite these research findings, several authors reported positive changes in quality of life based upon subjective reports of patients who used zinc-based products on wounds. These changes included soothing of red, irritated skin, ${ }^{4}$ antibacterial properties when combined with calamine and clioquinol, ${ }^{4}$ reduction in wound odor, ${ }^{8,17}$ pain reduction, ${ }^{8}$ and a cooling sensation when zinc impregnated bandages were applied to the leg. In agreement with this literature review, however, 
Table 2 Topical zinc in skin protection

\begin{tabular}{|c|c|c|c|c|}
\hline Study & Study size & Trial design & Methodology & Key findings \\
\hline Cameron et $\mathrm{al}^{15}$ & 35 patients with VLU & $\begin{array}{l}\text { Randomized } \\
\text { controlled trial }\end{array}$ & $\begin{array}{l}\text { Evaluation of no-sting barrier film } \\
\text { (alcohol-free liquid) compared to } \\
\text { zinc paste }\end{array}$ & $\begin{array}{l}\text { No difference in wound healing } \\
\text { between the groups. Significantly } \\
\text { less time was spent on removing } \\
\text { the no-sting film barrier }\end{array}$ \\
\hline Schuren et al $^{16}$ & $\begin{array}{l}9 \text { studies involving } \\
\text { patients with VLU }\end{array}$ & $\begin{array}{l}\text { Systematic } \\
\text { review }\end{array}$ & $\begin{array}{l}\text { Evaluation of the clinical effectiveness } \\
\text { of no-sting film barrier (film-forming } \\
\text { liquid acrylate) compared to zinc, } \\
\text { petrolatum, and other skin protectants }\end{array}$ & $\begin{array}{l}\text { No difference in protective } \\
\text { properties. Significant reports } \\
\text { of pain control and improved } \\
\text { comfort when no-sting film } \\
\text { barrier was used }\end{array}$ \\
\hline
\end{tabular}

Abbreviation: VLU, venous leg ulcers.

patients have reported sensitivities to the constituent of paste bandages which included reports of burning, stinging, itching, and tingling when the bandages were applied to inflamed skin. ${ }^{1,2,4,18}$ Although these sensitivities are thought to occur rarely, ${ }_{1}^{1}$ patch testing may help avoid the use of the modality in patients who are sensitive. ${ }^{2,4}$ In addition, one author reported that the sensitivities thought to be attributed to zinc oxide may actually be associated with other products added to the bandages and not the zinc alone. ${ }^{1}$

Additional concerns have been identified when utilizing zinc-based dressings. These include interference with the daily routines of the patient, ${ }^{8}$ and less comfort when using a zinc-based product when compared to a hydrocolloid combined with a stocking. ${ }^{8}$ When compared to a hydrocolloid under Coban compression, Unna boots were reported as less easy to use, ${ }^{6}$ and were less cosmetically appealing. ${ }^{8}$ In addition, since zinc paste bandages are applied wet and contract as they dry out, there is a concern that the bandages can constrict blood flow to the lower limb. ${ }^{17}$

\section{Conclusion}

There is insufficient evidence based upon this current literature review to verify that topical zinc products are effective in treating wounds due to chronic venous insufficiency. Of the 14 studies reported in this review, only six were from the last decade (2004-2015), which demonstrates a need for new research examining the role of topical zinc in the treatment of wounds due to venous insufficiency. In addition, six of the examined studies ( $43 \%$ ) had fewer than 40 subjects, four (28.5\%) had between 40 and 90 subjects, while the remaining four $(28.5 \%)$ were systematic reviews, meta-analyses, or had more than 120 subjects. In this light, additional studies focusing on vigorous scientific research with larger sample sizes are needed to demonstrate the efficacy (if any) of topical zinc in the treatment of venous wounds. Of all the studies examined, only three studies reported favorable outcomes in the use of topical zinc. ${ }^{7,12,14}$ However, in one of these studies the authors reported compression, and not the zinc-based product, may have been the factor attributed to improved healing. ${ }^{14}$ Other factors may be taken into account when clinicians select wound care products for patients with venous leg ulcers. Other treatments such as CircAid Thera-boots and hydrocolloid dressings have been reported to be as effective as zinc-based products in healing wounds, but are reported to be more cost-effective. ${ }^{9,10}$ Additionally, subjective patient reports were varied. Some authors reported patients had decreased pain, ${ }^{6,16,19}$ increased comfort, ${ }^{16}$ and improved ease of use $e^{6,15,19,20}$ when wounds were treated with products such as hydrocolloids, four-layer compression systems, and no-sting barrier films in direct comparison to zinc-based products. In addition, one author reported sensitivities to zinc products ${ }^{13}$ and another reported that patients found zinc products cosmetically unappealing. ${ }^{8}$

Since it is anticipated that zinc products will continue to be used in the treatment of venous ulcers, additional studies are warranted. Future research should include larger, highquality trials focusing on objective outcome measures as well as quality of life issues and cost-effectiveness of treatments. In a time of increased cost pressures, high-quality research is needed when making treatment choices for patients with venous leg ulcers. Wound care practices based upon evidence could have a long-term impact on the resources available to clinicians and quality of life of patients suffering from venous wounds.

\section{Disclosure}

The author has no conflicts of interest to disclose.

\section{References}

1. Lansdown AB, Mirastschijski U, Stubbs N, Scanlon E, Ågren MS. Zinc in wound healing: theoretical, experimental, and clinical aspects. Wound Repair Regen. 2007;15(1):2-16.

2. O'Connor S, Murphy S. Chronic venous leg ulcers: is topical zinc the answer? A review of the literature. Adv Skin Wound Care. 2014;27(1):35-44.

3. Rostan EF, DeBuys HV, Madey DL, Pinnell SR. Evidence supporting zinc as an important antioxidant for skin. Int J Dermatol. 2002;41(9): 606-611. 
4. Williams C. Examining the range of medicated and paste-impregnated bandages. Br J Nurs. 1999;8(15):1019-1020.

5. Henzel JH, DeWeese MS, Lichti EL. Zinc concentrations within healing wounds. Significance of postoperative zincuria on availability and requirements during tissue repair. Arch Surg. 1970;100(4):349-357.

6. Koksal C, Bozkurt AK. Combination of hydrocolloid dressing and medical compression stockings versus Unna's boot for the treatment of venous leg ulcers. Swiss Med Wkly. 2003;133(25-26):364-368.

7. Hendricks WM, Swallow RT. Management of stasis leg ulcers with Unna's boots versus elastic support stockings. $J$ Am Acad Dermatol. 1985;12(1 Pt 1):90-98.

8. Cordts PR, Hanrahan LM, Rodriguez AA, Woodson J, Lamorte WW, Menzoian JO. A prospective, randomized trial of Unna's boot versus Duoderm CGF hydroactive dressing plus compression in the management of venous leg ulcers. J Vasc Surg. 1992;15(3):480-486.

9. Kerstein M, Gahtan V. Outcomes of venous ulcer care: results of a longitudinal study. Ostomy Wound Manage. 2000;46(6):22-26, 28-29.

10. DePalma RG, Kowallek D, Spence RK, et al. Comparison of costs and healing rates of two forms of compression in treating venous ulcers. Vasc Endovascular Surg. 1999;33(6):683-690.

11. Luz BS, Araujo CS, Atzingen DA, Mendonça AR, Mesquita Filho M, Medeiros ML. Evaluating the effectiveness of the customized Unna boot when treating patients with venous ulcers. An Bras Dermatol. 2013;88(1):41-49.

12. Strömberg HE, Ågren MS. Topical zinc oxide treatment improves arterial and venous leg ulcers. Br J Dermatol. 1984;111(4):461-468.
13. Brandrup F, Menne T, Agren M, Strömberg H, Holst R, Frisen M. A randomized trial of two occlusive dressings in the treatment of leg ulcers. Acta Derm Venereol. 1989;70(3):231-235.

14. Stacey M, Jopp-Mckay A, Rashid P, Hoskin S, Thompson P. The influence of dressings on venous ulcer healing - a randomised trial. Eur $J$ Vasc Endovasc Surg. 1997;13(2):174-179.

15. Cameron J, Hoffman D, Wilson J, Cherry G. Comparison of two periwound skin protectants in venous leg ulcers: a randomised controlled trial. J Wound Care. 2005;14(5):233-236.

16. Schuren J, Becker A, Gary Sibbald R. A liquid film-forming acrylate for peri-wound protection: a systematic review and meta-analysis $\left(3 \mathrm{M}^{\mathrm{TM}}\right.$ Cavilon $^{\mathrm{TM}}$ no-sting barrier film). Int Wound J. 2005;2(3):230-238.

17. Smith G, Simon D, McDermott E, Gibson E. Incorporating novel solutions to lower-limb problems into compression formularies. $\mathrm{Br} J$ Community Nurs. 2014;Suppl:S37-S44.

18. Parboteeah S, Brown A. Managing chronic venous leg ulcers with zinc oxide paste bandages. Br J Nurs. 2008;17(6):S30, S32, S34-S36.

19. Amsler F, Willenberg T, Blättler W. In search of optimal compression therapy for venous leg ulcers: a meta-analysis of studies comparing divers bandages with specifically designed stockings. $J$ Vasc Surg. 2009;50(3):668-674.

20. Polignano R, Boneado P, Gasbarro S, Allegra C. A randomised controlled study of four-layer compression versus Unna's Boot for venous ulcers. J Wound Care. 2004;13(1):21-24.

\section{Publish your work in this journal}

Chronic Wound Care Management and Research is an international, peer reviewed, open access, online journal publishing original research, reviews, editorials, and commentaries on the causes and management of chronic wounds and the major issues related to chronic wound management. Topics also include chronic wounds as comorbidities to other

\section{Dovepress}

conditions, patient adherence to therapy, and the economic burden of chronic wounds. The manuscript management system is completely online and includes a very quick and fair peer review system, which is all easy to use. Visit http://www.dovepress.com/testimonials.php to read real quotes from published authors. 